\title{
Phenanthroindolizidine alkaloids from Vincetoxicum pumilum
}

Stærk, Dan; Nezhad, Koorosh B.; Asili, Javad; Emami, Saied A,; Ahi, Ali; Sairafianpour, Majid; Jaroszewski, Jerzy W.

Published in:

Biochemical Systematics and Ecology

DOI:

10.1016/j.bse.2005.01.004

Publication date:

2005

Document version

Publisher's PDF, also known as Version of record

Citation for published version (APA):

Stærk, D., Nezhad, K. B., Asili, J., Emami, S. A., Ahi, A., Sairafianpour, M., \& Jaroszewski, J. W. (2005).

Phenanthroindolizidine alkaloids from Vincetoxicum pumilum. Biochemical Systematics and Ecology, 33, 957960. https://doi.org/10.1016/j.bse.2005.01.004 


\title{
Phenanthroindolizidine alkaloids from Vincetoxicum pumilum
}

\author{
Dan Stærk $^{\text {a }}$, Koorosh Bahrami Nezhad ${ }^{\mathrm{a}}$, \\ Javad Asili ${ }^{b}$, Saied Ahmad Emami ${ }^{b}$, \\ Ali Ahi ${ }^{\mathrm{b}}$, Majid Sairafianpour ${ }^{\mathrm{a}}$, \\ Jerzy W. Jaroszewski ${ }^{\text {a,* }}$ \\ a Department of Medicinal Chemistry, The Danish University of Pharmaceutical Sciences, \\ Universitetsparken 2, DK-2100 Copenhagen, Denmark \\ ${ }^{\mathrm{b}}$ Department of Pharmacognosy, Faculty of Pharmacy, Mashhad University of Medical Sciences, \\ Vakilabad Boulvard, P.O. Box 91775-1365, Mashhad, Iran
}

Received 21 May 2004; accepted 7 January 2005

\section{Subject and source}

Vincetoxicum pumilum Decne. [syn. Alexitoxicon pumilum (Decne.) Pobed., Antitoxicum pumilum (Decne.) Pobed., Cynanchum pumilum (Decne.) Bornm.] (Apocynaceae-Asclepiadoideae) is a perennial herb endemic to Central Asia (Jalili and Jamzad, 1999). The plant (roots and aerial parts) was collected in Deh-Ghaibi near Mashhad, Iran. A voucher specimen (accession number 35007) was deposited in herbarium FUMH (Ferdowsi University Mashhad Herbarium).

\footnotetext{
* Corresponding author. Tel:: +45 3530 6372; fax: +45 35306040 .
}

E-mail address: jj@dfuni.dk (J.W. Jaroszewski). 


\section{Previous work}

There are no literature reports of phytochemical investigations of $V$. pumilum.

\section{Present study}

Dried and milled roots $(310 \mathrm{~g})$ and aerial parts $(568 \mathrm{~g})$ were repeatedly extracted with a 1:1 mixture of methanol and dichloromethane. The extracts were evaporated and the residues ( $27 \mathrm{~g}$ from the roots and $59 \mathrm{~g}$ from the aerial parts) were suspended in water at $\mathrm{pH} \mathrm{2-3,} \mathrm{extracted} \mathrm{with} \mathrm{diethyl} \mathrm{ether,} \mathrm{the} \mathrm{solutions} \mathrm{alkalized} \mathrm{with}$ aqueous ammonia, and re-extracted with diethyl ether. The resulting alkaloid fraction of the root extract $(560 \mathrm{mg})$ was fractionated by LC $[75 \times 2 \mathrm{~cm}$ column of Matrex silica gel 60A $(35-70 \mu \mathrm{m}), \mathrm{CH}_{2} \mathrm{Cl}_{2}-\mathrm{CH}_{3} \mathrm{OH}-28 \%$ aqueous $\mathrm{NH}_{3}$ (93:6:1 followed by 90:10:1)] and HPLC [25 × $2.1 \mathrm{~cm}$ column of LiChrosorb Si60 $(5 \mu \mathrm{m})$, $\mathrm{CH}_{2} \mathrm{Cl}_{2}$-saturated methanolic $\mathrm{NH}_{3}$ (97:3) and $\mathrm{CH}_{2} \mathrm{Cl}_{2}-\mathrm{CH}_{3} \mathrm{OH}-28 \%$ aqueous $\mathrm{NH}_{3}$ (92.5:6.5:1)] to give $70 \mathrm{mg}$ of (-)-13a $\alpha$-antofine (1), $2 \mathrm{mg}$ of (-)-10 $\beta, 13 \mathrm{a} \alpha-$

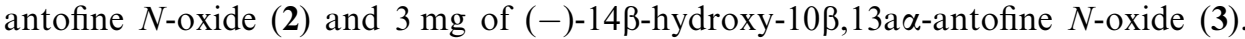
Similarly, fractionation of the alkaloid fraction from the aerial parts $(800 \mathrm{mg})$ by HPLC as above gave $7 \mathrm{mg}$ of $\mathbf{1}, 3 \mathrm{mg}$ of $\mathbf{2}$, and $2 \mathrm{mg}$ of $\mathbf{3}$.

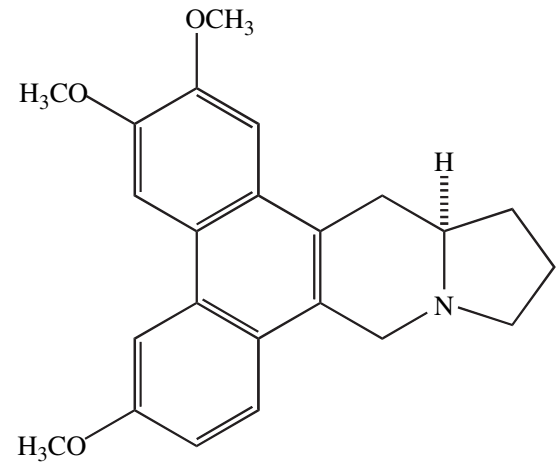

1.<smiles>[R]C1c2c(c3ccc(OC)cc3c3cc(OC)c(OC)cc23)C[N@@+]2([O-])CCC[C@H]12</smiles>

2. $\mathrm{R}=\mathrm{H}$

3. $\mathrm{R}=\mathrm{OH}$

The compounds were identified by comparison of their ${ }^{1} \mathrm{H}$ and ${ }^{13} \mathrm{C}$ NMR spectra with literature data (Stærk et al., 2000, 2002). Compound 1: $[\alpha]_{\mathrm{D}}^{25}-118^{\circ}$ (c $0.3, \mathrm{CHCl}_{3}$ ), lit. $-124^{\circ}$ (Stærk et al., 2002); compound 2: $[\alpha]_{\mathrm{D}}^{25}-56^{\circ}(c 0.3$, $\mathrm{CHCl}_{3}$ ), lit. $-37^{\circ}$ (Stærk et al., 2000); compound 3: CD spectrum $\left(\mathrm{CH}_{3} \mathrm{OH}\right)$ showed positive Cotton effects at $211 \mathrm{~nm}$ and $233 \mathrm{~nm}$ and a negative Cotton effect at $268 \mathrm{~nm}$, in agreement with the literature (Stærk et al., 2000). 


\section{Chemotaxonomic significance}

The genus Vincetoxicum Wolf [Cynanchum sect. Vincetoxicum (Wolf) Tsiang \& P. T. Li] has traditionally been classified within the cosmopolitan family Asclepiadaceae. However, the traditionally defined Asclepiadaceae have long been regarded as an apomorphic derivative of the Apocynaceae. Recently, a unified classification of Apocynaceae s. 1. has been provided on the basis of extensive morphological studies as well as cladistic interpretation of molecular data (Endress and Bruyns, 2000; Endress and Stevens, 2001; Potgieter and Albert, 2001). Apocynaceae s. 1. thus include Asclepiadaceae and Periplocaceae, reduced to a subfamily status (Endress and Bruyns, 2000). Most recent studies focus on subtribal classification within the Asclepiadoideae (Liede, 1999; Liede and Kunze, 2002; Liede and Meve, 2001, 2002; Liede and Täuber, 2002; Rapini et al., 2003). Although taxonomic interpretations of Vincetoxicum Wolf and Cynanchum L. and their relationships are complex, the former genus appears to be more related to Tylophora $\mathrm{R}$. Br. rather than to the latter (Liede, 1996; Liede and Kunze, 2002; Yamashiro et al., 2004). Vincetoxicum and Tylophora produce phenanthroindolizidine alkaloids (Govindachari, 1967; Bick and Sinchai, 1981; Ali and Bhutani, 1989; Capo and Saa, 1989; Li et al., 1989; Lavault et al., 1994; Abe et al., 1995, 1998; Stærk et al., 2000, 2002; Huang et al., 2002; Zhen et al., 2002), absent from the Old World Cynanchum s. s. (sections Cynanchum and Rhodostegiella). The presence of phenanthroindolizidine alkaloids in $V$. pumilum is thus consistent with the most recent views (Liede, 1996; Yamashiro et al., 2004) on taxonomy of the phylogenetically complex Asclepiadeae. The phenanthroindolizidine alkaloids such as antofine are also of interest, because they exhibit potent antitumor activity by a mode of action different from known antitumor drugs (Gao et al., 2004).

\section{References}

Abe, F., Iwase, Y., Yamauchi, T., Honda, K., Hayashi, N., 1995. Phytochemistry 39, 695.

Abe, F., Hirokawa, M., Yamauchi, T., Honda, K., Hayashi, N., Ishii, M., Imagawa, S., Iwahana, M., 1998. Chem. Pharm. Bull. 46, 767.

Ali, M., Bhutani, K.K., 1989. Phytochemistry 28, 3513.

Bick, I.R.C., Sinchai, W., 1981. Alkaloids, vol. 19. Academic Press, 193 pp.

Capo, M., Saa, J.M., 1989. J. Nat. Prod. 52, 389.

Endress, M.E., Bruyns, P.V., 2000. Bot. Rev. 66, 1.

Endress, M.E., Stevens, W.D., 2001. Ann. MO Bot. Gard 88, 517.

Gao, W., Lam, W., Zhong, S., Kaczmarek, C., Baker, D.C., Cheng, Y.-C., 2004. Cancer Res. 64, 678.

Govindachari, T.R., 1967. Alkaloids, vol. 9. Academic Press, 517 pp.

Huang, X.S., Yu, S.S., Liang, X.T., 2002. Chin. Chem. Lett. 13, 61.

Jalili, A., Jamzad, Z., 1999. Red Data Book of Iran. Research Institute of Forests and Rangelands, Tehran, 22 pp.

Lavault, M., Richomme, P., Bruneton, J., 1994. Pharm. Acta Helv. 68, 225.

Li, X., Peng, J., Onda, M., Konda, Y., Iguchi, M., Harigaya, Y., 1989. Heterocycles 29, 1797.

Liede, S., 1996. Taxon 45, 193.

Liede, S., 1999. Blumea 44, 471.

Liede, S., Meve, U., 2001. Novon 11, 171. 
Liede, S., Meve, U., 2002. Nord. J. Bot. 22, 579.

Liede, S., Kunze, H., 2002. Org. Divers. Evol. 2, 239.

Liede, S., Täuber, A., 2002. Syst. Bot. 27, 789.

Potgieter, K., Albert, V.A., 2001. Ann. MO Bot. Gard. 88, 523.

Rapini, A., Chase, M.W., Goyder, D.J., Griffiths, J., 2003. Taxon 52, 33.

Stærk, D., Christensen, J., Lemmich, E., Duus, J.Ø., Olsen, C.E., Jaroszewski, J.W., 2000. J. Nat. Prod. 63, 1584

Stærk, D., Lykkeberg, A., Christensen, J., Budnik, B., Abe, F., Jaroszewski, J.W., 2002. J. Nat. Prod. 65,1299

Yamashiro, T., Fukuda, T., Yokoyama, J., Maki, M., 2004. Mol. Phylogenet. Evol. 31, 689.

Zhen, Y., Huang, X., Yu, D., Yu, S., 2002. Zhiwu Xuebao 44, 349. 